\title{
Effect of the injection of an extract of Ascaris suum on macrophage activation during the early phase of Mycobacterium bovis BCG infection in C57BI/6 mice
}

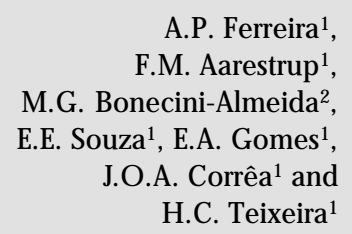

A.P. Ferreira',

F.M. Aarestrup ${ }^{1}$,

M.G. Bonecini-Almeida2, E.E. Souza ${ }^{1}$, E.A. Gomes ${ }^{1}$, J.O.A. Corrêa ${ }^{1}$ and H.C. Teixeira ${ }^{1}$

\author{
${ }^{1}$ Laboratório de Imunologia, Instituto de Ciências Biológicas, \\ Universidade Federal de Juiz de Fora, Juiz de Fora, MG, Brasil \\ ${ }^{2}$ Laboratório de Imunologia Celular, Centro de Pesquisa Evandro Chagas, \\ Fundação $\mathrm{O}$ svaldo Cruz, Rio de Janeiro, RJ, Brasil
}

\section{Correspondence \\ A.P. Ferreira \\ Laboratório de Imunologia \\ ICB, UFJF \\ Campus Universitário \\ 36036-330 Juiz de Fora, MG \\ Brasil \\ Fax: + 55-32-229-3790 \\ E-mail: anapaula@icb.ufjf.br}

Presented at the Meeting "NO Brazil, Basic and Clinical Aspects of Nitric O xide", Foz do Iguaçu, PR, Brazil, March 10-13, 1999.

Research supported by FAPEM IG and $\mathrm{CNPq}$.

Received June 17, 1999 Accepted August 30, 1999

\section{Abstract}

Injection of an Ascaris suum extract (Asc) affects both the humoral and cellular immune responses to unrelated antigens when it is coadministered with these antigens. In the present study we evaluated the effect of Asc on macrophage activation in the early phase of Mycobacterium bovis BCG (Pasteur strain TMCC 1173) infection in C57Bl/6 mice. $\mathrm{C} 57 \mathrm{Bl} / 6$ mice were injected intraperitoneally (ip) with $0.1 \mathrm{mg}$ BCG (BCG group) or BCG plus $1 \mathrm{mg}$ Asc (BCG + Asc group). The peritoneal exudates were obtained at 2, 7 and 14 days after infection. The numbers of IFN- $\gamma$-secreting cells were assessed by the ELISPOT assay. Nitric oxide (NO) production was measured by the Griess method and by the evaluation of NADPH diaphorase activity in the peritoneal exudates. The administration of Asc extract increased NADPH diaphorase activity ( 2 days: control $=0, \mathrm{BCG}=7 \%, \mathrm{BCG}+$ $\mathrm{Asc}=13 \%$, and $\mathrm{Asc}=4 \% ; 7$ days: control $=4, \mathrm{BCG}=13 \%, \mathrm{BCG}+$ $\mathrm{Asc}=21 \%$, and $\mathrm{Asc}=4.5 \%$ ) and TNF- $\alpha$ levels (mean $\pm \mathrm{SD} ; 2$ days: control $=0, \mathrm{BCG}=169 \pm 13, \mathrm{BCG}+\mathrm{Asc}=202 \pm 37$, and Asc $=0 ; 7$ days: control $=0, \mathrm{BCG}=545 \pm 15.5, \mathrm{BCG}+\mathrm{Asc}=2206 \pm 160.6$, and Asc $=126 \pm 26 ; 14$ days: control $=10 \pm 1.45, \mathrm{BCG}=9 \pm 1.15, \mathrm{BCG}$ $+\mathrm{Asc}=126 \pm 18$, and $\mathrm{Asc}=880 \pm 47.67 \mathrm{pg} / \mathrm{ml}$ ) in the early phase of $\mathrm{BCG}$ infection. Low levels of NO production were detected at 2 and 7 days after $B C G$ infection, increasing at 14 days (mean \pm SD; 2 days: control $=0, \mathrm{BCG}=3.7 \pm 1.59, \mathrm{BCG}+\mathrm{Asc}=0.82 \pm 0.005, \mathrm{Asc}=0.48$ $\pm 0.33 ; 7$ days: control $=0, \mathrm{BCG}=2.78 \pm 1.54, \mathrm{BCG}+\mathrm{Asc}=3.07 \pm$ 1.05, $\mathrm{Asc}=0 ; 14$ days: control $=0, \mathrm{BCG}=9.05 \pm 0.53, \mathrm{BCG}+\mathrm{Asc}=$ $9.61 \pm 0.81, \mathrm{Asc}=10.5 \pm 0.2\left(2 \times 10^{6}\right)$ cells $\left./ \mathrm{ml}\right)$. Furthermore, we also observed that Asc co-injection induced a decrease of BCG-colonyforming units (CFU) in the spleens of BCG-infected mice during the first week of infection (mean $\pm \mathrm{SD} ; 2$ days: $\mathrm{BCG}=1.13 \pm 0.07$ and $\mathrm{BCG}+\mathrm{Asc}=0.798 \pm 0.305 ; 7$ days: $\mathrm{BCG}=1.375 \pm 0.194$ and $\mathrm{BCG}$ $+\mathrm{Asc}=0.548 \pm 0.0226 ; 14$ days: $\mathrm{BCG}=0.473 \pm 0.184$ and $\mathrm{BCG}+\mathrm{Asc}$ $\left.=0.675 \pm 0.065\left(\mathrm{x} \mathrm{10} 0^{2}\right) \mathrm{CFU}\right)$. The present data suggest that Asc induces the enhancement of the immune response in the early phase of BCG infection.

\section{Key words}

- Mycobacterium bovis

- Ascaris suum

- Macrophage activation

- TNF- $\alpha$

- NADPH diaphorase 


\section{Introduction}

The capacity of helminths to modulate host immune responses to unrelated antigens is well documented (1). High dose immunization with adult Ascaris suum worm antigen (Asc) induces a marked production of IL-4 and IL- 10 by inguinal and periaortical lymph node (LN) cells of DBA/2 mice (2). Asc-injected DBA/2 mice, when simultaneously immunized with ovalbumin (OA), exhibit a marked suppression of both OAspecific cutaneous delayed type hypersensitivity (DTH) and in vitro proliferative capacity of LN cells. In addition, OA-induced IL2 , IFN- $\gamma$ and IL-4 production was diminished in Asc-treated mice and was associated with an impairment of the OA-specific $\operatorname{IgG} 2 \mathrm{a}, \operatorname{IgG} 1$ and $\operatorname{IgE}$ humoral immune response (2). Similarly, Asc induces a significant decrease of $M$. bovis-specific DTH in BCG-infected mice 14 days after infection (3). Since persons in developing countries who are at risk for mycobacterial infections often have $A$. suum co-infection, these observations may have very important public health implications.

Protection against intracellular pathogens operates in two stages, i.e., an early innate nonspecific response followed by acquired immunity with a strong DTH response (4). During the first week of infection, the early innate immune response is the main mechanism controlling mycobacterial proliferation. After two weeks of infection, cellular immunity develops and immature granulomas are formed. After 4 weeks, the cellular immunity reaches its peak and is represented by epithelioid granulomas that are associated with the decrease of mycobacterial load (4-6). In inbred strains of mice, early innate resistance to $M$. bovis $\mathrm{BCG}$ infection is controlled $(5,7,8)$ by a single dominant gene designated Nramp (natural resistance-associated macrophage protein) that regulates the priming activation of macrophages for nitric oxide (NO) production.
For example, mice genetically resistant to M. bovis $\mathrm{BCG}$ infection $(\mathrm{C} 3 \mathrm{H} / \mathrm{HeN}$ and $\mathrm{A} / \mathrm{J})$ are able to prevent $M$. bovis proliferation without expressing a strong DTH response. In contrast, genetically susceptible mice (C57B1/6, B10.A and BALB/c) only control mycobacterial proliferation by the acquisition of an effective cellular immune response (5).

Thus, the immune mechanisms associated with the regulation of resistance and susceptibility in the innate early phase of BCG infection clearly involve cytokines and NO production $(4,9)$. As mentioned above, injection of $A$. suum extract decreases $M$. bovis-specific immune responses during the stages of infection controlled by cellular immunity (3). To determine whether it also affects early innate responses to these organisms, we studied whether co-injection of A. suum extract alters NO production in a model of intraperitoneal (ip) BCG infection in $\mathrm{C} 57 \mathrm{Bl} / 6$ mice. In this study, we measured NADPH diaphorase activity as a histochemical marker for nitric oxide synthase (iNOS; NOS2), the enzyme which catalyzes oxidation of L-arginine to L-citrulline and the production of NO $(10,11)$. Since several studies have demonstrated that IFN- $\gamma$ and TNF- $\alpha(6,12,13)$ are important cytokines correlated with the development of NO-mediated nonspecific early host defense, we also measured these cytokines. Surprisingly, our findings suggest that Asc administration in M. bovis BCG-infected mice increases both NADPH diaphorase activity and TNF- $\alpha$ production by peritoneal cells and is correlated with a reduction of BCGcolony forming unit (CFU) numbers in the spleen.

\section{Material and Methods}

\section{Animals}

Female C57B1/6 mice were obtained from the Reproduction Biology Center, UFJF and were maintained in the animal facilities of 
the Biological Sciences Institute, UFJF, where they were housed in plastic cages with unlimited access to food and water. Mice were used in the experiments at 6-8 weeks of age. Three main groups of mice were studied: group BCG - three mice injected ip with BCG; group BCG + Asc - three mice injected $i p$ with BCG + Asc; group Asc - three mice injected $i p$ with Asc only.

\section{M. bovis BCG infection and CFU enumeration}

M. bovis BCG, Pasteur TMCC 1173 strain, was thawed, washed in phosphatebuffered saline (PBS) and inoculated at a dose of $0.1 \mathrm{mg}$ in $0.5 \mathrm{ml}$ PBS by ip injection. At 2, 7 and 14 days post-infection, BCGCFU were counted in the spleen. Briefly, spleens were collected and homogenized individually in $1 \mathrm{ml}$ PBS using a teflon-coated tissue homogenizer (Glas-Col Apparatus Co., Terre Haute, IN, USA). Serial ten-fold dilutions of organ homogenates in PBS were prepared and plated onto Middlebrook 7H10 Bacto Agar (Difco Laboratories, Detroit, MI, USA) plates in triplicate. Plates were sealed in plastic bags and incubated at $37^{\circ} \mathrm{C}$ for 14 days, and the number of bacteria per organ was determined.

\section{Ascaris suum extract preparation and injection}

The animals were injected $i p$ with $1 \mathrm{mg}$ of adult worm extract from $A$. suum, prepared as described by Macedo and Mota (14). Briefly, live worms obtained from pig intestines were washed with PBS and mixed with an equal volume of borate-buffered saline (BBS), pH 8.0. After homogenization in an Ultra-Turrax apparatus and centrifugation at $10,000 \mathrm{rev} / \mathrm{min}$ for $1 \mathrm{~h}$, the precipitate was resuspended in $400 \mathrm{ml}$ of BBS and stirred overnight at $4^{\circ} \mathrm{C}$. This suspension was centrifuged again and the supernatant was dialyzed against distilled water over- night in the cold. A clear supernatant obtained after centrifugation at $10,000 \mathrm{rev} / \mathrm{min}$ for $2 \mathrm{~h}$ was aliquoted and lyophilized.

\section{D iaphorase cytochemistry}

Peritoneal cavities were washed with 5 $\mathrm{ml}$ of PBS to remove resident macrophages. Cell suspensions were washed once and resuspended to obtain $10^{6}$ cells $/ \mathrm{ml}$. Slides were prepared using cytospin (FANEM, São Paulo, SP, Brazil) with $2 \times 10^{5}$ cells per well, left to dry at room temperature, fixed in cold acetone for $10 \mathrm{~min}$, wrapped in plastic film and kept at $-20^{\circ} \mathrm{C}$ prior to use. Slides were stained with $50 \mathrm{mM}$ Tris, $\mathrm{pH} 8$, with $0.3 \mathrm{mM}$ nitroblue tetrazolium (Sigma Chemical Co., St. Louis, MO, USA), 1 mM NADPH, 0.2\% Triton X-100 for $30 \mathrm{~min}$ at $37^{\circ} \mathrm{C}$, washed, and mounted in glycerol, and dark-blue cells were enumerated using a light microscope at 40X magnitude. The macrophage-like cell line RAW 264-7 (ATCC, Rockville, MD, USA) was stimulated with $1 \mu \mathrm{g} / \mathrm{ml}$ of LPS (Sigma) and used as positive control for NADPH diaphorase activity.

\section{Measurement of nitrite release}

NO release was quantified by the accumulation of nitrite in the supernatants of peritoneal cell cultures after $48 \mathrm{~h}$ in culture with $10 \mu \mathrm{g} / \mathrm{ml}$ of BCG antigen, using the standard Griess method (15). Briefly, the supernatant was added to Griess reagent $(1: 1)$ freshly prepared prior to use and the preparation was left to stand at room temperature for $5 \mathrm{~min}$. Standards were prepared using sodium nitrite $(2-100 \mu \mathrm{M})$ and added to each assay plate. Absorbances at $570 \mathrm{~nm}$ were read with a spectrophotometer (Titertek Uniskan II, Flow, Inc., Lugano, Switzerland).

\section{Determination of TNF- $\alpha$ levels}

Peritoneal cells were collected and cul- 
tured for $48 \mathrm{~h}$ in RPMI-1640 medium with $10 \mu \mathrm{g} / \mathrm{ml}$ of BCG antigen. Supernatants were collected and TNF- $\alpha$ was quantitated by double sandwich ELISA using $2 \mu \mathrm{g} / \mathrm{ml}$ of purified anti-mouse TNF- $\alpha$ Ab (Pharmingen, San Diego, CA, USA) and $1 \mu \mathrm{g} / \mathrm{ml}$ of biotin rat anti-mouse TNF- $\alpha$ Ab (Pharmingen). Binding of biotinylated antibodies was detected using the streptavidin-biotinylated horseradish peroxidase complex (Southern Biotechnology Associates, Inc., Birmingham, AL, USA), OPD and $\mathrm{H}_{2} \mathrm{O}_{2}$ and stopped with $50 \mu \mathrm{l}$ of $0.2 \mathrm{M}$ citric acid. The plates were read at $450 \mathrm{~nm}$ with an ELISA reader (Titertek Uniskan II, Flow, Inc.). Samples were quantitated by comparison with standard curves of purified recombinant TNF- $\alpha$ (Pharmingen).

\section{Determination of IFN $-\gamma$}

The ELISPOT assay was used as previously described (16) to determine the frequency of IFN- $\gamma$-producing peritoneal cells. Briefly, milliliter filtration plates (STHA09610, Millipore, Bedford, MA, USA) were coated overnight at $4^{\circ} \mathrm{C}$ with anti-IFN- $\gamma(\mathrm{R} 4-6 \mathrm{~A} 2,1 \mu \mathrm{g} / \mathrm{ml})$. Wells were blocked with $1 \%$ BSA-PBS for $2 \mathrm{~h}$ at $37^{\circ} \mathrm{C}$. Appropriate dilutions of peritoneal cells in $5 \%$ FCS-RPMI were added in a volume of $100 \mu \mathrm{l}$ and incubated with $10 \mu \mathrm{g} / \mathrm{ml}$ of BCG antigen for $16 \mathrm{~h}$ at $37^{\circ} \mathrm{C}$ in $7 \% \mathrm{CO}_{2}$. Plates were thoroughly washed with PBS-Tween $20(0.05 \%)$, before adding aliquots of 100

Figure 1 - Effect of Ascaris suum extract on NADPH diaphorase activity in cells obtained from C57BI/ 6 mice injected with BCG, $\mathrm{BCG}+$ Asc or Asc. Results are reported as percent of dark cells indicating NADPH diaphorase activity of one representative experiment with duplicate measurements per data point. $* \mathrm{P}<0.05$ compared to BCG (Student t-test).

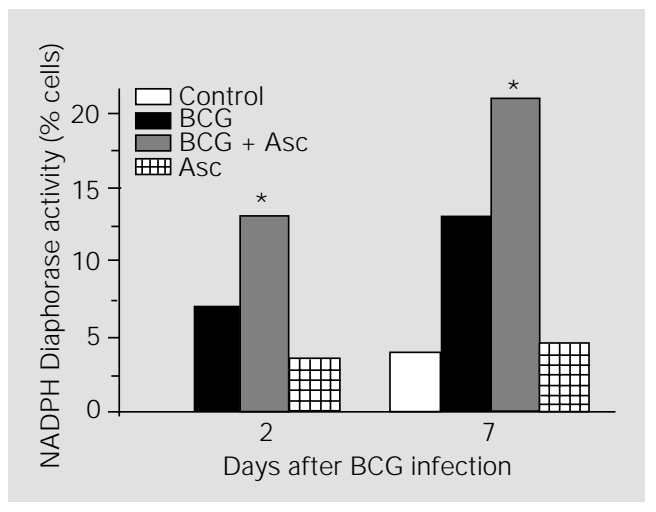

$\mu 1 /$ well of biotinylated anti-IFN- $\gamma$ mAb (AN-18.17.24, $0.5 \mu \mathrm{g} / \mathrm{ml}$; kindly provided by Drs. Mahasti Sahihi de Macedo and Ises A. Abrahmsohn, USP, São Paulo). After incubation at $37^{\circ} \mathrm{C}$ for $2 \mathrm{~h}$, plates were washed with PBS-Tween 20 several times and avidin-alkaline phosphates (Sigma) were added. After 1 -h incubation at $37^{\circ} \mathrm{C}$, plates were washed 8 times with PBS-Tween 20 and twice with alkaline phosphate buffer, $\mathrm{pH} 9.5$ and the substrate, 5-bromo-4-chloro-3-indoyl phosphate (Fluka, Basel, Switzerland), was added. After $15 \mathrm{~min}$, blue dots had developed and the reaction was stopped with distilled water. Individual spots were counted under a dissecting microscope at $32 \mathrm{X}$ magnification.

\section{Statistical analysis}

The Student $t$-test was used to determine significant differences between the different groups of mice, with the level of significance set at $\mathrm{P}<0.05$.

\section{Results}

\section{Ascaris suum extract increased NADPH diaphorase activity}

A high proportion of peritoneal macrophages from BCG-infected animals injected or not with Asc extract were positive by diaphorase cytochemistry. However, BCGinfected mice injected with Asc extract increased 2-fold their capacity to induce diaphorase activity $(\mathrm{P}<0.05)$. Control and Ascinjected mice showed a reduced percentage of positive cells (Figure 1).

\section{Nitrite production in peritoneal cell cultures}

Supernatants of peritoneal cells from animals injected with $\mathrm{BCG}, \mathrm{BCG}+\mathrm{Asc}$ or Asc were collected after $48 \mathrm{~h}$ of culture with BCG antigen, and the amount of $\mathrm{NO}$ was evaluated (Figure 2). Low levels of NO 
production were detected at 2 and 7 days after BCG infection, increasing at 14 days post-infection (pi). No significant difference $(\mathrm{P}<0.05)$ in $\mathrm{NO}$ production by peritoneal cells was observed between BCG-injected mice and $\mathrm{BCG}+\mathrm{Asc}$-injected mice. In addition, a high level of NO production was also detected in mice injected only with Asc on the 14th day.

\section{Effect of Asc on TNF- $\alpha$ production in peritoneal cell cultures}

The kinetics of TNF- $\alpha$ production was measured in supernatant culture during the early phase of BCG infection (Figure 3). TNF- $\alpha$ was detectable in the supernatants at 2, 7 and 14 days pi. At 2 days after BCG infection TNF- $\alpha$ was observed in mice injected with BCG and mice injected with $\mathrm{BCG}+$ Asc. However, at day 7 there was a significant increase $(\mathrm{P}<0.05)$ in TNF- $\alpha$ levels produced by mice injected with $\mathrm{BCG}+$ Asc compared with mice injected only with BCG. At the end of the early phase of BCG infection (day 14) there were detectable lower levels of TNF- $\alpha$ in mice injected with BCG + Asc. In mice injected only with Asc, higher TNF- $\alpha$ levels were observed at 14 days after Asc injection.

\section{Presence of IFN- $\gamma$-producing cells during intraperitoneal BCG infection}

The ELISPOT assay was used for the determination of frequency of IFN- $\gamma$-producing peritoneal cells (Table 1). Cells $\left(10^{5}\right)$ were cultured with $10 \mu \mathrm{g} / \mathrm{ml}$ of BCG antigen for 24 h. Numbers of spontaneous IFN- $\gamma$ spot-forming cells (SFC) were evaluated at 7 days after BCG infection with or without Asc injection. No significant differences were demonstrated between mice injected with BCG or $\mathrm{BCG}+$ Asc. In contrast, mice injected with Asc presented significantly $(\mathrm{P}<0.05)$ lower numbers of SFC when compared with mice injected with $\mathrm{BCG}$ or $\mathrm{BCG}+$ Asc.

\section{Asc interferes with BCG proliferation in spleen}

The number of CFU was investigated in the early phase of BCG infection (Figure 4). A significant reduction in number of BCGCFU was observed during the first week of BCG infection in mice injected with BCG + Asc when compared with mice injected only with BCG ( 2 and 7 days pi). However, by the
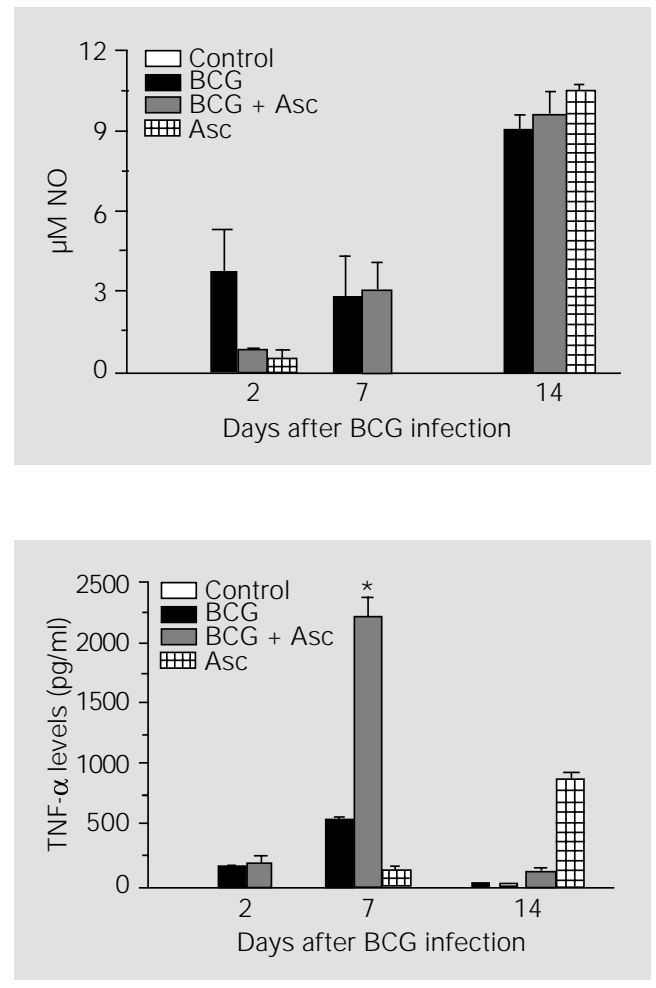

Table 1 - Frequencies of IFN- $\gamma$ spot-forming cells (SFC) in C57BI/6 at 7 days pi.

Results are reported as mean \pm SD of one representative experiment with duplicate measurements per data point. $* \mathrm{P}<0.05$ compared to $\mathrm{BCG}$ and BCG + Asc (Student t-test).

\begin{tabular}{lc} 
Groups & $\begin{array}{r}\text { Number of IFN }-\gamma \mathrm{SFC} / 10^{6} \text { peritoneal } \\
\text { cells (mean } \pm \text { SD) }\end{array}$ \\
\hline Control & $15 \pm 1.2$ \\
BCG & $706 \pm 25.6$ \\
BCG + Asc & $749 \pm 6.2$ \\
Asc & $400 \pm 10.0^{*}$
\end{tabular}

Figure 2 - Effect of Ascaris suum extract on NO production in $\mathrm{C} 57 \mathrm{BI} / 6$ mice. NO was measured with the Griess reagent. Peritoneal cells $\left(2 \times 10^{5}\right)$ were incubated for $48 \mathrm{~h}$ with $10 \mu \mathrm{g} / \mathrm{ml}$ of BCG antigen at $37^{\circ} \mathrm{C}$ in $5 \%$ $\mathrm{CO}_{2}$ and absorbance was determined at $540 \mathrm{~nm}$. Results are reported as mean \pm SD of one representative experiment with duplicate measurements per data point.

Figure 3 - Effect of Ascaris suum extract on TNF- $\alpha$ production in culture of peritoneal cells of C57BI/6 mice during BCG infection. Supernatants were harvested $48 \mathrm{~h}$ after stimulation with $10 \mu \mathrm{g} / \mathrm{ml}$ of BCG antigen and measured by two-sandwich ELISA. Kinetic TNF- $\alpha$ data are expressed as mean $\pm \mathrm{SD}$ (pg/ $\mathrm{ml}$ ) of one representative experiment with quadruplicate measurements per data point. * $\mathrm{P}<0.05$ compared to BCG and BCG + Asc groups (Student t-test). 
end of the early phase of BCG infection there was no significant difference in number of BCG-CFU between the BCG group and the $\mathrm{BCG}+\mathrm{Asc}$ group.

\section{Discussion}

In the present experiment we investigated the effect of Asc extract during the early phase of ip BCG infection in $\mathrm{C} 57 \mathrm{Bl} / 6$. The immune response of BCG-infected mice was evaluated on the basis of NO production, NADPH diaphorase activity, numbers of IFN- $\gamma$-secreting cells, TNF- $\alpha$ production by peritoneal cells and number of BCG-CFU in the spleen. The data demonstrated that BCG infection (ip) induced NADPH diaphorase activity, NO production, TNF- $\alpha$ and IFN- $\gamma$ production during the development of the early phase of infection ( 2 weeks pi) in C57Bl/6 mice. The administration of Asc extract (group II) increased NADPH diaphorase activity and TNF- $\alpha$ levels in the early phase of BCG infection. Furthermore, we also observed that Asc injection induced a decrease of BCG-CFU in the spleens of BCGinfected mice during the first week of infection.

BCG administration to BCG-susceptible mice (C57Bl/6, BALB/c and B10.A) generated an efficient protective early response to the challenge with homologous BCG and heterologous pathogens (Lysteria monocy-

Figure 4 - Effect of Ascaris suum extract on the number of BCGCFU in the spleen of BCG-infected mice. At the indicated periods, spleens were recovered and bacterial counts (BCG-CFU) performed as described. Data represent mean \pm SD numbers of BCG-CFU (two animals per data point) from triplicates of one representative experiment. $* \mathrm{P}<0.05$ compared to $\mathrm{BCG}$ group (Student t-test).

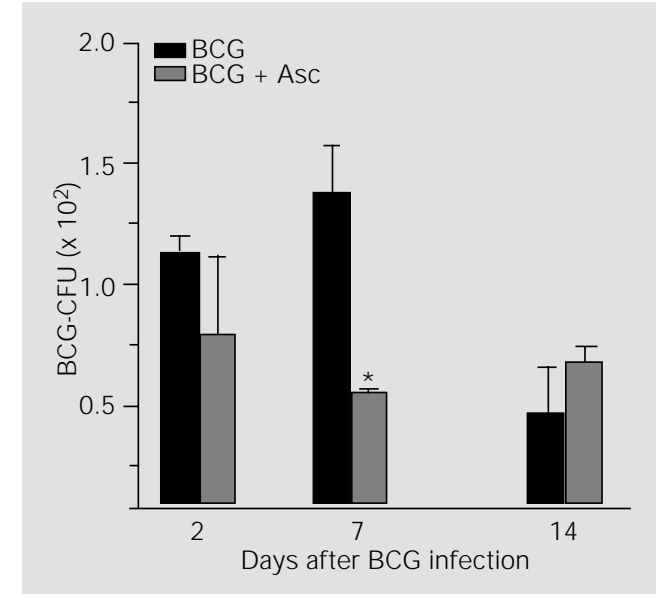

togenes) (5). It was also demonstrated that BCG administration restricted Mycobacterium avium proliferation and, at the same time, promoted expression of TNF- $\alpha$ mRNA and IFN- $\gamma$ mRNA in spleen cells, suggesting that these cytokines act in an additive or synergistic fashion in the induction of bacteriostasis (17). In vitro TNF- $\alpha$ was produced by macrophages upon stimulation with rIFN$\gamma$ and mycobacterial infection and both cytokines are crucial for activation of macrophage functions (18). Our data demonstrate that Asc extract in BCG-susceptible mice $(\mathrm{C} 57 \mathrm{Bl} / 6)$ is associated with the development of a protective early response to $\mathrm{BCG}$ represented by a reduction of BCG-CFU in the spleen. In addition, the present results suggest that the enhancement of TNF- $\alpha$ production and NADPH diaphorase activity is probably associated with the induction of a protective immune response.

The murine resistance to an intracellular pathogen upon genetic regulation of the Nramp gene is correlated with the priming/ activation of macrophages linked to TNF- $\alpha$ dependent production of antimicrobial NO (19). In studies using NADPH diaphorase histochemistry and PCR it was observed that macrophages in the lungs of people with active Mycobacterium tuberculosis often express catalytically competent nitric oxide synthase (20). Yoshida et al. (4) showed that C57B1/B10 mice presented high levels of iNOS protein and mRNA at 3 and 6 days after intravenous BCG infection. Our results for $\mathrm{C} 57 \mathrm{Bl} / 6$ mice also demonstrated the participation of iNOS in the early phase of BCG infection. Additionally, the results also support the hypothesis that the production of TNF- $\alpha$ is closely linked to the levels of NADPH diaphorase activity.

In the present study we did not observe significant differences in $\mathrm{NO}$ production between group $\mathrm{BCG}$ and group $\mathrm{BCG}+\mathrm{Asc}$. Some studies have reported the presence of iNOS protein associated with little or no synthesized NO in human (21) and mouse 
macrophages. In our experiment it is possible that the nitrite produced in the supernatants of peritoneal cells was utilized by macrophages in their activation during culture.

Many studies have demonstrated that Asc impaired important $\mathrm{T}$ cell functions for cellmediated and humoral responses to other antigens by the induction of a predominantly Th2 type response with increases in IL-4 and IL-10 (2,22,23). Interestingly, it was recently found that the mechanism by which IL-10 inhibits macrophage killing of schistosomes involves suppression of TNF- $\alpha$ production, and can be reversed by the addition of exogenous TNF- $\alpha$ (24). The ability of mice to develop DTH after subcutaneous BCG immunization was inhibited by the administration of Asc extract (3). In the present study, we investigated the effect of Asc injection during the early phase of $\mathrm{BCG}$ infection during the development of innate nonspecific host immune response. We observed that the administration of Asc induces increased resistance against BCG infection in a susceptible strain of mice. Therefore, our data suggest that the effect of Asc might be influenced by the stage of the host response developed during BCG infection. Finally, we postulate that Asc has different effects on the innate immune response and acquired immune response in BCG-infected mice and that these responses are correlated.

\section{Acknowledgments}

The authors would like to thank Dr. W. Evan Secor and George L. Freeman Jr., DPD/ $\mathrm{NCID/CDC}$, for a critical reading of the manuscript.

\section{References}

1. Barriga OO (1984). Immunomodulation by nematodes: a review. Veterinary Parasitology, 14: 299-320.

2. Ferreira AP, Faquim ES, Abrahamsohn IA \& Macedo MS (1995). Immunization with Ascaris suum extract impairs T cell functions in mice. Cellular Immunology, 162: 202-210.

3. Macedo MS \& Barbuto J AM (1988). Murine delayed type hypersensitivity is suppressed by Ascaris suum extract. Brazilian J ournal of Medical and Biological Research, 21: 523-525.

4. Yoshida A, Koide Y, Masato U \& Yoshida TO (1995). Dissection of strain difference in acquired protective immunity against Mycobacterium bovis Calmette-Guérin bacillus (BCG). J ournal of Immunology, 155: 2057-2066.

5. Pelletier $M$, Forget $A$, Bourassa $D$, Gros $P$ \& Skamene E (1982). Immunopathology of BCG infection in genetically resistant and susceptible mouse strains. J ournal of Immunology, 129: 2179-2185.

6. Vidal SM, Malo D, Vogan K, Skamene E \& Gros P (1993). Natural resistance to infection with intracellular parasites: Isolation of a candidate for Bcg. Cell, 73: 469-485.

7. Brown DH, Lafuse $W \&$ Zwilling BS (1995). Cytokine-mediated activation of macrophages from Mycobacterium bovis BCG-resistant and susceptible mice: Differential effects of corticosterone on antimycobacterial activity and expression of the Bcg gene (candidate Nramp). Infection and Immunity, 63: 2983-2988.

8. Aarestrup FM, Gonçalves-da-Costa SC \& Sarno EN (1995). The effect of thalidomide on BCG-induced granulomas in mice. Brazilian J ournal of Medical and Biological Research, 28: 1069-1076.

9. Bala S, Hastings $K L$, Kazempour $K$, Inglis S \& Dempsey WL (1998). Inhibition of tumor necrosis factor alpha alters resistance to Mycobacterium avium complex infection in mice. Antimicrobial Agents and Chemotherapy, 42: 2336-2341.

10. Tracey WR, Nakane M, Pollock JS \& Forstermann U (1993). Nitric oxide synthases in neuronal cells, macrophages and endothelium are NADPH diaphorases, but represent only a fraction of total cellular NADPH diaphorase activity. Biochemical and Biophysical Research Communications, 195: 1035-1040.

11. Talavera E, Martinez-Lorenzana G, Corkidi G, Léon-Olea M \& Condés-Lara M (1997). NADPH-diaphorase-stained neurons after experimental epilepsy in rats. Nitric Oxide: Biology and Chemistry, 1: 484-493.
12. Green SJ, Scheller LF, Marletta MA, Seguin MC, Klotz FW, Slayter M, Nelson BJ \& Nacy CA (1995). Nitric oxide: Cytokine regulation of nitric oxide in host resistance to intracellular pathogens. Immunology Letters, 43: 87-94.

13. Yang J, Kawamura I, Zhu H \& Mitsuyama M (1995). Involvement of natural killer cells in nitric oxide production by spleen cells after stimulation with Mycobacterium bovis BCG. J ournal of Immunology, 155: 5728-5735.

14. Macedo MS \& Mota I (1980). Antigenic competition in IgE antibody production: I. Establishment of parameters involved in primary and secondary responses. Immunology, 40: 701-708.

15. Ding A, Nathan CF \& Stuehr DJ (1988). Release of reactive nitrogen intermediates and reactive oxygen intermediates from mouse peritoneal macrophages: comparison of activating cytokines and evidence for independent production. J ournal of Immunology, 141: 2407-2503.

16. Teixeira HC, Munk ME \& Kaufmann SHE (1995). Frequencies of IFN- $\gamma$ and IL-4-producing cells during Mycobacterium bovis BCG infection in two genetically susceptible mouse strains: role of $\alpha / ß$ T cells and NK1.1 cells. Immunology Letters, 46: 15-19. 
17. Appelberg R \& Orme IM (1993). Effector mechanisms involved in cytokine-mediated bacteriostasis of Mycobacterium avium infections in murine macrophages. Immunology, 80: 352-359.

18. Flesh IE, Hess J H, Oswald IP \& Kaufmann SH (1994). Growth inhibition of Mycobacterium bovis by IFN-gamma stimulated macrophages: regulation by endogenous tumor necrosis factor-alpha and by IL-10. International Immunology, 6: 693-700.

19. Formica S, Roach A \& Blackwell J M (1994). Interaction with extracellular matrix proteins influences Lsh/Bcg (candidate Nramp) gene regulation of macrophage priming/activation for tumor necrosis factor- $\alpha$ and nitrite release. Immunology, 82: 42-50.
20. Nicholson S, Bonecini-Almeida MG, Lapa e Silva J R, Nathan C, Xie Q, Munford R, Weidner J R, Calaycay J , Geng J , Boechat N, Linhares C, Rom W \& Ho J L (1996). Inducible nitric oxide synthase in pulmonary alveolar macrophages from patients with tuberculosis. J ournal of Experimental Medicine, 183: 2293-2302.

21. Weinberg J B, Misukonis MA, Wood ER, Smith GL, Shami PL, Mason SN \& Granger DL (1993). Human mononuclear phagocyte nitric oxide synthase (NOS): evidence for induction of NOS mRNA and protein without detectable capacity for nitric oxide production. Blood, 82: 186-201.

22. Faquim-Mauro EL \& Macedo MS (1998). The immunosuppressive activity of Ascaris suum is due to high molecular weight components. Clinical and Experimental Immunology, 114: 245-251.

23. Macedo MS, Faquim-Mauro E, Ferreira AP \& Abrahamsohn IA (1998). Immunomodulation induced by Ascaris suum extract in mice: Effect of anti-interleukin-4 and anti-interleukin-10 antibodies. Scandinavian J ournal of Immunology, 47: 10-18.

24. Oswald IP, Wynn TA, Sher A \& J ames SL (1992). Interleukin 10 inhibits macrophage microbicidal activity by blocking the endogenous production of tumor necrosis factor $\alpha$ required as a costimulatory factor for interferon $\gamma$ induced activation. Proceedings of the National Academy of Sciences, USA, 89: 8676-8680. 